\title{
Feed preference of grower ostriches consuming diets differing in Lupinus angustifolius inclusion levels
}

\author{
T. S. Brand ${ }^{1,2, \#}$, J. A. Engelbrecht ${ }^{2}$, J. van der Merwe $^{2}$ \& L. C. Hoffman ${ }^{2}$ \\ ${ }^{1}$ Directorate: Animal Sciences, Department of Agriculture, Western Cape Government, Private Bag X1, Elsenburg, 7607, \\ South Africa \\ ${ }^{2}$ Department of Animal Sciences, University of Stellenbosch, Private Bag X1, Matieland, 7602, South Africa
}

(Received 5 May 2017; Accepted 7 November 2017; First published online 1 December 2017)

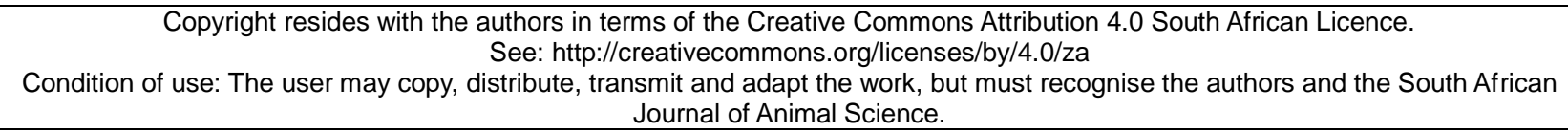

\begin{abstract}
Feed costs contribute the largest proportion of the input costs of slaughter birds in an intensive ostrich production unit. Alternative, cheaper feedstuffs, such as lupins (sweet and bitter cultivars), were therefore evaluated to determine the optimal lupin inclusion level in ostrich rations without affecting feed preference and intake. Sixty South African Black ostriches were randomly divided into ten paddocks of six birds per paddock. Three trials, with five different experimental diets, were conducted to investigate the diet preference of grower ostriches in a free-choice system. Feed and water were supplied ad libitum. The position of the diets in the successive paddocks was varied by rotating the five feed troughs in a clockwise direction, but within each paddock the position of each feeder and diet stayed the same throughout the three trials. In the first two trials, sweet (trial 1) or bitter (trial 2) lupins replaced soybean oilcake meal to have $0,7.5,15,22.5$, and $30 \%$ lupin inclusion levels in the diet. In trial 3 the soybean oilcake meal was replaced with either sweet or bitter lupins to have dietary inclusion levels as follows: $0 \%$ lupins, $15 \%$ sweet, $15 \%$ bitter, $30 \%$ sweet, or $30 \%$ bitter. The daily intake per group for each diet was monitored over a period of five days each. The average initial body weight of the birds was $73.6 \pm 0.5 \mathrm{~kg}$. No interaction was found between day and diet for the three trials and dry matter intake (DMI) did not differ between the five treatments for any of the three trials. In the second trial the birds tended to show a preference for the $7.5 \%$ bitter lupin inclusion level and discriminated against the $15 \%$ and $30 \%$ bitter lupin inclusion levels. Regression analysis of DMI on lupin inclusion rates revealed no significant trends. In conclusion, the study revealed that soybean oilcake meal can be replaced in the diets of grower ostriches by sweet lupin inclusion levels up to $30 \%$, without any significant detrimental effect on diet preference and feed intake.
\end{abstract}

Keywords: Alkaloids, dry matter intake, feed palatability, lupins, visual appearance of the feed

\# Corresponding author: tersb@elsenburg.com

\section{Introduction}

Feed costs make the largest proportion (ca. 75\%) of the input costs of slaughter birds in an intensive ostrich production unit (Brand et al., 2000; Brand \& Gous, 2006; Jordaan et al., 2008). Volatile feed prices, seasonal droughts, exchange rates, and market trends (consumer preference and economic cycles) have a large effect on the profitability of ostrich production. It is thus of cardinal importance to optimise the aspects of the ostrich production unit which can be controlled by the producer, such as nutrition (Carstens, 2013). Least-cost diet formulations and the use of alternative protein sources are two ways of decreasing feeding costs; however it is important that this does not have a detrimental effect on the quality of the end products.

Protein sources are becoming scarcer and more expensive, especially for use in animal feeds (Brand et al., 2004a; Laudadio \& Tufarelli, 2011). Depending on the feeding phase (pre-starter, starter, grower or finisher), protein composes up to $22.5 \%$ of a balanced diet (Brand \& Gous, 2006). Ostrich producers are therefore looking for alternative, locally-produced protein sources that are less expensive but still deliver acceptable production yields. Lupins have been identified as one possibility. It has already been successfully included in the diets of both monogastric (Brand et al., 1995) and ruminant animals (Brand et al., 1992; Brand et al., 1997), and in some cases have effectively replaced previously-used protein sources such as 
soybean oilcake meal. However, it is important to note that due to the presence of anti-nutritional factors, such as alkaloids, lupins can only be included at certain levels for efficient utilisation and to prevent undesirable effects (Brand \& Brandt, 2000; Tufarelli et al., 2015). This problem is to some extent eliminated by the presence of sweet (low in alkaloids, $<0.1 \%$ ) and bitter (alkaloid-rich, $0.1-4.0 \%$ ) varieties within the species. To reduce the risk of toxicity an alkaloid level of less than $0.6 \mathrm{~g} / \mathrm{kg}$ is deemed suitable for animal feeds (McDonald et al., 2011). The low alkaloid content of the sweet lupin varieties makes their use in diets with prolonged intakes of little concern regarding toxicity for the animal (Laudadio \& Tufarelli, 2011).

According to Ferguson et al. (2002), under certain circumstances, commercial farm animals can make a rational choice between feeds according to their nutritional needs. Brand et al. (2004b) provided five types of lupins to young ostriches in a free-choice system and noted that in addition to smell and taste, colour and previous exposure to a certain type of feed may have an influence on feed preference. It has been found in the industry that young growing and finisher birds in feedlots refuse to eat feed when the composition or physical characteristics are suddenly changed. This phenomenon is generally observed when feed with a relatively green colour is changed to a feed that is less green in colour. Birds therefore need to be gradually exposed to a new feed to avoid a decrease in intake and consequently a drop in production (Brand, 2008).

Milton et al. (1994) found during a field study on food selection by ostriches in Southern Africa that ostriches did not feed on toxic plants. The authors assumed that the birds identified these species by sight but also suggested that taste and smell may also play a role in determining the palatability of the feed, as while the ostriches were foraging, they occasionally dropped plucked plant material. It therefore seems that when ostriches check the quality of a feed they conduct a preliminary visual inspection, as well as utilising taste and smell. Chemoreceptive events in the mouth and olfactory epithelium are responsible for the final recognition and selection of the feed. These structures trigger the emotional experience of acute pleasure or displeasure (Kruger, 2007).

The aim of this study was to determine to what degree lupins (sweet and bitter cultivars) can be included in ostrich rations without affecting feed preference and intake. A regression analysis of the mean DMI per bird per treatment diet was performed over the different lupin inclusion levels (\%) to establish the feed intake $(\mathrm{kg} / \mathrm{day})$ of ostriches when diets containing different levels of lupins (sweet and bitter cultivars) were fed. The time that the birds were exposed to the different diets was also taken into consideration to determine if the time of feeding had any effect on their feed preference. The colour of the feed was determined by the CIE Lab-System in to determine whether the diets in the respective trails were similar in colour.

\section{Materials and methods}

The study was conducted in July 2015 at the Oudtshoorn Research Farm in the Klein Karoo region of South Africa (situated at longitude $22^{\circ} 15^{\prime} \mathrm{E}$ and latitude $33^{\circ} 37^{\prime} \mathrm{S}$ at an altitude of $300 \mathrm{~m}$ above sea level). The experimental design included 60 South African Black ostriches of 43 weeks of age that were randomly divided into 10 paddocks with six birds per paddock. The average initial body weight of the birds was $73.6 \pm$ $0.5 \mathrm{~kg}$. Ethical clearance (R14/108) for this study was granted by the Elsenburg ethical committee.

Three trials with five experimental diets per trial were conducted to investigate the diet preference of grower ostriches in a free-choice system. In Trials 1 and 2, soybean oilcake meal was replaced by sweet (Trial 1) or bitter (Trial 2) lupins in a step-wise manner to produce five experimental diets with lupin inclusion levels of $0 \%, 7.5 \%, 15 \%, 22.5 \%$, and $30 \%$. Trial 3 differed from Trial 1 and 2 in that soybean oilcake meal was replaced by alternatively sweet or bitter lupins to provide diets with $0 \%$ lupins, $15 \%$ sweet, $15 \%$ bitter, $30 \%$ sweet, and $30 \%$ bitter lupin inclusion levels. The positions of the feeders containing each diet in the successive paddocks were altered by rotating the five feed troughs in a clockwise direction, but within each paddock the specific position of each feeder and diet stayed the same throughout the three trials. The feed troughs were spread more or less evenly within each paddock and provided sufficient feeding space per bird. The approximate dimensions of the feed troughs were $46 \mathrm{~cm} \times 23 \mathrm{~cm} \times 20 \mathrm{~cm}$ and of the paddocks, $32 \mathrm{~m} \times$ $30 \mathrm{~m}$. Both feed and water were provided ad libitum, with the dimensions of the water buckets being $29 \mathrm{~cm} x$ $20 \mathrm{~cm} \times 15 \mathrm{~cm}$.

The daily intake of each diet per group was monitored over a period of five days for each trial. This was done by weighing back the refusals of the day and subtracting it from the amount of feed offered during the day. The feed in the feed troughs was mixed twice daily (early in the morning and at midday) by hand to stimulate feed intake. The recording of feed provided and feed refused occurred at the same time every day. Despite inclement weather conditions on certain days of the trial periods, data capturing was completed without disruptions.

The treatment diets were formulated using Mixit2+ feed formulation software $\AA$ (Agricultural Software Consultants Inc., San Diego, USA). The raw material composition of the sweet and bitter lupins and soybean oilcake meal used in the diet formulations of this study can be found in Table 1. The raw material samples 
were grounded using a RetschTM ZM200 sample mill (Haan, Germany) with a $1.5 \mathrm{~mm}$ screen to create a meal with a consistent particle size. Thereafter the raw materials were analysed using the methods of the Association of Official Analytical Chemists (AOAC, 2002) for dry matter (DM) (method 934.01), ash (method 942.05), crude protein (CP) (method 976.05), crude fibre (CF) (method 962.09), ether extract (EE) (method 920.39), acid detergent fibre (ADF) (Goering \& van Soest, 1970), neutral detergent fibre (NDF) (Robertson \& van Soest, 1981). The calcium (Ca) and phosphorous $(P)$ values were analysed using method 6.1.1 (Dry Ashing) of the Agri Laboratory Association of Southern Africa guidelines (ALASA) (ALASA, 1998).

Table 1 Raw material composition of the sweet and bitter lupins and soybean oilcake meal used in the diet formulations of this study

\begin{tabular}{lccc}
\hline Nutrient component $\mathbf{( g / k g )}$ & Sweet lupins & Bitter lupins & Soybean oilcake meal \\
\hline Dry matter & 902.5 & 898.7 & 910.8 \\
Ash & 29.5 & 26.2 & 62.5 \\
Crude protein & 309.4 & 313.8 & 463.1 \\
Crude fibre & 154.0 & 156.3 & 32.0 \\
Ether extract & 48.9 & 42.2 & 10.3 \\
Neutral detergent fibre & 244.8 & 231.9 & 81.9 \\
Acid detergent fibre & 196.9 & 189.4 & 44.3 \\
Calcium & 2.60 & 2.60 & 2.90 \\
Phosphorous & 4.90 & 4.50 & 8.30 \\
\hline
\end{tabular}

The formulations of the diets are presented in Tables $2-4$. The experimental diets were mixed, milled and pelleted at the Kromme Rhee Research Farm (situated 18 $50^{\prime} \mathrm{E}, 33^{\circ} 37^{\prime} \mathrm{S}$ with an altitude of $177 \mathrm{~m}$ above sea level) and transported to the Oudtshoorn Research Farm. Tables 2 - 4 also provide the nutritional compositions of the experimental diets. These values were determined for samples randomly collected during the feed mixing and pelleting process. The samples were ground using a RetschTM ZM200 sample mill (Haan, Germany) with a $1.5 \mathrm{~mm}$ screen to create a meal with a consistent particle size. Thereafter, all samples of the same experimental diet were pooled and analysed for dry matter (DM), crude protein (CP), ether extract (EE), ash, crude fibre (CF), acid detergent fibre (ADF), neutral detergent fibre (NDF) and in vitro organic matter digestibility (IVOMD) using a Bran + Luebbe InfrAlyzer 500 near infrared reflectance spectrometer (IA-500) (NIRS). The samples (ca.6.0 g) were individually presented in closed cups and scanned in the reflectance mode at between $1100-2500 \mathrm{~nm}$ in the near-infrared region with $2 \mathrm{~nm}$ intervals, acquiring 701 data points for each sample. The spectroscopic measurements were interpreted using Bran + Leubbe SESAME Version 2.00 software (Bran + Luebbe GmbH, Norderstedt, Germany). The ME (MJ/kg feed) was calculated using the following equation: ME $=0.015 \times$ IVOMD ( $/ \mathrm{kg} \mathrm{DM}$ ) (Van der Honing \& Alderman, 1988). The IVOMD was determined by an adaptation of the method of the two-stage rumen fluidpepsin technique described by Tilley and Terry (1963). It involves firstly 48 hour fermentation by rumen micro-organisms in a buffer solution, followed by 48 hour pepsin-hydrochloric acid digestion. The residue represents the indigestible part of the sample.

The total alkaloid contents of the finely-ground pooled feed samples containing either the sweet (Eureka) or bitter (SSL 10) Lupinus angustifolius cultivars were determined as described by Boschin et al. (2008), with minor modifications. The sample preparation method was modified by extracting the total alkaloid content directly using a 50:50 methylene dichloride:methanol mixture (MDC:MeOH). GC-MS with a $30 \mathrm{~m} \times 0.25 \mathrm{~mm}$, internal diameter $0.25 \mu \mathrm{m}$, AT-Wax capillary column was then used to analyse the total alkaloid content. The temperature program was as follows: $150{ }^{\circ} \mathrm{C}$ for 5 minutes increased by $5{ }^{\circ} \mathrm{C}$ per minute up to $300{ }^{\circ} \mathrm{C}$ then maintained at $300^{\circ} \mathrm{C}$ for 15 minutes. Analyses were performed in split mode with a split ratio of $1: 25$. The injection volume was $1 \mu \mathrm{L}$, injection temperature $250{ }^{\circ} \mathrm{C}$, interface temperature $300^{\circ} \mathrm{C}$ and the acquisition was from $\mathrm{m} / \mathrm{z} 50$ to 450 . The source operated in El mode at eV. The total alkaloids were identified using Mass library (Agilent) and the detection limit for quantifying the total alkaloids was $100 \mathrm{~g} / \mathrm{ml}$. However, no alkaloids were found in the respective feed samples at this detection limit. Therefore, the sweet and bitter lupin cultivars used in this study were the same cultivars (sweet $L$. angustifolius and bitter $L$. angustifolius) used by Smith (2005). The spectrophotometry method described by Von Baer et al. (1978) was 
used to determine the total alkaloid content of these cultivars in the study by Smith (2005). This method is a quantitative determination of total alkaloids with bromocresol purple at $405 \mathrm{~nm}$. The total alkaloid content of the sweet and bitter lupin cultivars in the study by Smith (2005) was $49.1 \mathrm{mg} / \mathrm{kg}$ and $15204.5 \mathrm{mg} / \mathrm{kg}$ respectively. These values were used to calculate the estimated amount of total alkaloids of the five dietary treatments of this study for each of the three trials (Tables 2 - 4).

Table 2 The formulation and nutritional composition (as fed basis) of five treatment diets containing different sweet lupin inclusion levels fed to grower phase slaughter ostriches (Trial 1)

\begin{tabular}{|c|c|c|c|c|c|}
\hline \multirow{2}{*}{ Raw materials (kg/ton) } & \multicolumn{5}{|c|}{ Diet number and percentage lupin inclusion level } \\
\hline & $1(0 \%)$ & $2(7.5 \%)$ & $3(15 \%)$ & $4(22.5 \%)$ & $5(30 \%)$ \\
\hline Maize meal & 590.6 & 544.9 & 499.2 & 453.5 & 407.8 \\
\hline Soybean oilcake meal & 149.3 & 111.0 & 74.7 & 37.3 & 0.00 \\
\hline Sweet lupins & 0.00 & 76.5 & 152.9 & 226.5 & 300.0 \\
\hline Lucerne meal & 186.4 & 193.5 & 200.5 & 210.6 & 220.7 \\
\hline Molasses powder & 25.0 & 25.0 & 25.0 & 25.0 & 25.0 \\
\hline Monocalcium phosphate & 17.4 & 17.2 & 16.6 & 15.9 & 15.2 \\
\hline Limestone & 14.5 & 14.8 & 15.0 & 15.3 & 15.5 \\
\hline Salt & 10.0 & 10.0 & 10.0 & 10.0 & 10.0 \\
\hline Synthetic lysine & 0.87 & 0.76 & 0.65 & 0.53 & 0.42 \\
\hline Synthetic methionine & 0.41 & 0.43 & 0.45 & 0.46 & 0.48 \\
\hline Mineral and vitamin premix ${ }^{*}$ & 5.00 & 5.00 & 5.00 & 5.00 & 5.00 \\
\hline \multicolumn{6}{|l|}{ Nutrient component } \\
\hline $\mathrm{DM}^{1}(\mathrm{~g} / \mathrm{kg})$ & 893.9 & 911.2 & 900.1 & 911.8 & 901.5 \\
\hline$M E M J / k g$ feed ${ }^{2}$ & 13.4 & 13.7 & 13.5 & 13.7 & 13.5 \\
\hline $\operatorname{IVOMD}^{3}(\mathrm{~g} / \mathrm{kg})$ & 851.2 & 838.1 & 841.3 & 825.5 & 827.2 \\
\hline$C P^{4}(\mathrm{~g} / \mathrm{kg})$ & 160.3 & 163.5 & 169.9 & 159.9 & 175.8 \\
\hline Ash (g/kg) & 90.3 & 99.3 & 99.5 & 111.1 & 100.8 \\
\hline$E E^{5}(\mathrm{~g} / \mathrm{kg})$ & 22.8 & 28.0 & 26.8 & 28.2 & 33.1 \\
\hline $\mathrm{CF}^{6}(\mathrm{~g} / \mathrm{kg})$ & 67.1 & 89.2 & 74.7 & 88.9 & 88.1 \\
\hline $\operatorname{ADF}^{7}(\mathrm{~g} / \mathrm{kg})$ & 97.6 & 124.3 & 108.1 & 130.5 & 119.7 \\
\hline $\mathrm{NDF}^{8}(\mathrm{~g} / \mathrm{kg})$ & 166.4 & 206.5 & 173.0 & 204.2 & 188.0 \\
\hline Total alkaloid content (ppm) & 0.00 & 3.68 & 7.37 & 11.0 & 14.7 \\
\hline
\end{tabular}

${ }^{*}$ Refer to APPENDIX 1 for the composition of the vitamin and mineral premix for grower ostriches

${ }^{1}$ Dry matter

${ }^{2}$ Metabolisable energy

${ }^{3}$ In vitro organic matter digestibility

${ }^{4}$ Crude protein

${ }^{5}$ Ether extract

${ }^{6}$ Crude fibre

${ }^{7}$ Acid detergent fibre

${ }^{8}$ Neutral detergent fibre 
Table 3 The formulation and nutritional composition (as fed basis) of five treatment diets containing different bitter lupin inclusion levels fed to grower phase slaughter ostriches (Trial 2)

\begin{tabular}{|c|c|c|c|c|c|}
\hline \multirow{2}{*}{ Raw materials (kg/ton) } & \multicolumn{5}{|c|}{ Diet number and percentage lupin inclusion level } \\
\hline & $1(0 \%)$ & $2(7.5 \%)$ & $3(15 \%)$ & $4(22.5 \%)$ & $5(30 \%)$ \\
\hline Maize meal & 590.6 & 544.9 & 499.2 & 453.5 & 407.8 \\
\hline Soybean oilcake meal & 149.3 & 112.0 & 74.7 & 37.3 & 0.00 \\
\hline Bitter lupins & 0.00 & 76.5 & 152.9 & 226.5 & 300.0 \\
\hline Lucerne meal & 186.4 & 193.5 & 200.5 & 210.6 & 220.7 \\
\hline Molasses powder & 25.0 & 25.0 & 25.0 & 25.0 & 25.0 \\
\hline Monocalcium phosphate & 17.4 & 17.2 & 16.6 & 15.9 & 15.2 \\
\hline Limestone & 14.5 & 14.8 & 15.0 & 15.3 & 15.5 \\
\hline Salt & 10.0 & 10.0 & 10.0 & 10.0 & 10.0 \\
\hline Synthetic lysine & 0.87 & 0.76 & 0.65 & 0.53 & 0.42 \\
\hline Synthetic methionine & 0.41 & 0.43 & 0.45 & 0.46 & 0.48 \\
\hline Vitamin and vitamin premix* & 5.00 & 5.00 & 5.00 & 5.00 & 5.00 \\
\hline \multicolumn{6}{|l|}{ Nutrient component } \\
\hline $\mathrm{DM}^{1}(\mathrm{~g} / \mathrm{kg})$ & 893.9 & 902.6 & 898.0 & 908.0 & 902.0 \\
\hline ME MJ/kg feed ${ }^{2}$ & 12.8 & 12.6 & 12.6 & 12.2 & 12.3 \\
\hline $\operatorname{IVOMD}^{3}(\mathrm{~g} / \mathrm{kg})$ & 851.2 & 839.0 & 839.7 & 810.5 & 822.2 \\
\hline $\mathrm{CP}^{4}(\mathrm{~g} / \mathrm{kg})$ & 160.3 & 170.2 & 172.1 & 168.3 & 185.3 \\
\hline Ash (g/kg) & 90.3 & 94.5 & 102.9 & 98.3 & 103.8 \\
\hline $\mathrm{EE}^{5}(\mathrm{~g} / \mathrm{kg})$ & 22.8 & 26.9 & 28.6 & 31.0 & 29.5 \\
\hline $\mathrm{CF}^{6}(\mathrm{~g} / \mathrm{kg})$ & 67.1 & 84.4 & 79.1 & 102.9 & 96.1 \\
\hline $\operatorname{ADF}^{7}(g / k g)$ & 97.6 & 115.7 & 112.4 & 134.8 & 126.6 \\
\hline $\operatorname{NDF}^{8}(\mathrm{~g} / \mathrm{kg})$ & 166.4 & 192.5 & 186.7 & 210.0 & 199.4 \\
\hline Total alkaloid content (ppm) & 0.00 & 1140.3 & 2280.7 & 3421.0 & 4561.4 \\
\hline
\end{tabular}

${ }^{*}$ Refer to APPENDIX 1 for the composition of the vitamin and mineral premix for grower ostriches

${ }^{1}$ Dry matter

${ }^{2}$ Metabolisable energy

${ }^{3}$ In vitro organic matter digestibility

${ }^{4}$ Crude protein

${ }^{5}$ Ether extract

${ }^{6}$ Crude fibre

${ }^{7}$ Acid detergent fibre

${ }^{8}$ Neutral detergent fibre 
Table 4 Formulation and nutritional composition (as fed basis) of five treatment diets containing sweet or bitter lupins at different inclusion levels fed to grower phase slaughter ostriches (Trial 3)

\begin{tabular}{|c|c|c|c|c|c|}
\hline \multirow{2}{*}{ Raw materials (kg/ton) } & \multicolumn{5}{|c|}{ Diet number and percentage lupin inclusion level } \\
\hline & $\begin{array}{c}1 \\
(0 \%)\end{array}$ & $\begin{array}{c}2 \\
(15 \% \text { Sweet) }\end{array}$ & $\begin{array}{c}3 \\
\text { (15\% Bitter) }\end{array}$ & $\begin{array}{c}4 \\
\text { (30\% Sweet) }\end{array}$ & $\begin{array}{c}5 \\
\text { (30\%Bitter) }\end{array}$ \\
\hline Maize meal & 590.6 & 544.9 & 544.9 & 407.8 & 407.8 \\
\hline Soybean oilcake meal & 149.3 & 112.0 & 112.0 & 0.00 & 0.00 \\
\hline Sweet lupins & 0.00 & 76.5 & 0.00 & 300.0 & 0.00 \\
\hline Bitter lupins & 0.00 & 0.00 & 76.5 & 0.00 & 300.0 \\
\hline Lucerne meal & 186.4 & 193.5 & 193.5 & 220.7 & 220.7 \\
\hline Molasses powder & 25.0 & 25.0 & 25.0 & 25.0 & 25.0 \\
\hline Monocalcium phosphate & 17.4 & 17.2 & 17.2 & 15.2 & 15.2 \\
\hline Limestone & 14.5 & 14.8 & 14.8 & 15.5 & 15.5 \\
\hline Salt & 10.0 & 10.0 & 10.0 & 10.0 & 10.0 \\
\hline Synthetic lysine & 0.87 & 0.76 & 0.76 & 0.42 & 0.42 \\
\hline Synthetic methionine & 0.41 & 0.43 & 0.43 & 0.48 & 0.48 \\
\hline Mineral and vitamin premix ${ }^{*}$ & 5.00 & 5.00 & 5.00 & 5.00 & 5.00 \\
\hline \multicolumn{6}{|l|}{ Nutrient component } \\
\hline $\mathrm{DM}^{1}(\mathrm{~g} / \mathrm{kg})$ & 893.9 & 900.1 & 898.0 & 901.5 & 902.0 \\
\hline$M E M J / k g$ feed ${ }^{2}$ & 12.8 & 12.6 & 12.6 & 12.4 & 12.3 \\
\hline $\operatorname{IVOMD}^{3}(\mathrm{~g} / \mathrm{kg})$ & 851.2 & 841.3 & 839.7 & 827.2 & 822.2 \\
\hline $\mathrm{CP}^{4}(\mathrm{~g} / \mathrm{kg})$ & 160.3 & 169.9 & 172.1 & 175.8 & 185.3 \\
\hline Ash $(\mathrm{g} / \mathrm{kg})$ & 90.3 & 99.5 & 102.9 & 100.8 & 103.8 \\
\hline$E E^{5}(\mathrm{~g} / \mathrm{kg})$ & 22.8 & 26.8 & 28.6 & 33.1 & 29.5 \\
\hline$C F^{6}(g / k g)$ & 67.1 & 74.7 & 79.1 & 88.1 & 96.1 \\
\hline $\operatorname{ADF}^{7}(g / k g)$ & 97.6 & 108.1 & 112.4 & 119.7 & 126.6 \\
\hline $\operatorname{NDF}^{8}(\mathrm{~g} / \mathrm{kg})$ & 166.4 & 173.0 & 186.7 & 188.0 & 199.4 \\
\hline Total alkaloid content (ppm) & 0.00 & 7.37 & 2280.7 & 14.7 & 4561.4 \\
\hline
\end{tabular}

${ }^{*}$ Refer to APPENDIX 1 for the composition of the vitamin and mineral premix for grower ostriches

${ }^{1}$ Dry matter

${ }^{2}$ Metabolisable energy

${ }^{3}$ In vitro organic matter digestibility

${ }^{4}$ Crude protein

${ }^{5}$ Ether extract, ${ }^{6}$ Crude fibre

${ }^{7}$ Acid detergent fibre

${ }^{8}$ Neutral detergent fibre

The mineral compositions and amino acid profiles of the diets are presented in Tables 5 - 7. To determine the mineral content of the pooled reference samples the finely ground (passed through a $1.5 \mathrm{~mm}$ sieve) feed samples were analysed using method 6.1.1 (Dry Ashing) as described in ALASA (ALASA, 1998). A $1-3 \mathrm{~g}$ sample of each diet was weighed and placed in a porcelain crucible. The crucibles were placed in a muffle furnace and left to ash overnight at $460-480^{\circ} \mathrm{C}$. Once the samples had cooled down, $5 \mathrm{ml}$ of $1: 1$ hydrogen chloride $(\mathrm{HCl})$ was added to each crucible to dissolve the samples. The crucibles were then placed in an oven for 30 minutes at $60^{\circ} \mathrm{C}$ for evaporation to take place. The samples were left to cool and then filled to a total volume of $40 \mathrm{ml}$ with deionized water and mixed thoroughly before being filtered into an amber bottle. The mineral concentrations was measured using a Thermo Electron iCAP 6000 Series Inductively Coupled Plasma (ICP) Spectrophotometer (Thermo Electron Corporation, Milan, Italy) fitted with a vertical quartz torch and Cetac ASX-520 autosampler. Concentrations were determined using Merck Titrisol standards with concentrations of 1000 ppm (Merck, Darmstadt, Germany) and calculated using iTEVA Analyst software. 
The amino acid profiles were determined using the method described by Grace Davison (2008), through hydrolysis of the samples in hydrochloric acid and high pressure liquid chromatography (HPLC). In a hydrolysis tube, $6 \mathrm{ml}$ of $6 \mathrm{~N} \mathrm{HCl}$ and $15 \%$ Phenol solution was added to $0.1 \mathrm{~g}$ of feed sample. Nitrogen was then added and the samples were placed under vacuum. This was done by flushing the hydrolysis tube with the nitrogen to remove oxygen and create an anaerobic environment. The sealed hydrolysis tubes were then placed in an oven for 24 hours at $110^{\circ} \mathrm{C}$ to allow complete protein hydrolysis. The samples were left to cool and then filtered using a hydrophylic polyvinylidene difluoride syringe filter (PVDF - $0.45 \mu \mathrm{m}, 33 \mathrm{~mm}$ ) before being transferred into $1.5 \mathrm{ml}$ Eppendorf tubes. Amino acids were derivatised with o-phthalaldehyde and 3mercaptopropionic acid in borate buffer (Agilent Technologies, Waldbronn, Germany). Reverse-phase Dionex HPLC (Dionex Corporation, California, USA) was used to separate the amino acids on a $3.9 \times 150$ $\mathrm{mm} \mathrm{C18} \mathrm{Nova-Pak} \mathrm{column} \mathrm{(Waters,} \mathrm{Ireland)} \mathrm{at} \mathrm{a} 1.1 \mathrm{ml} /$ minute flow rate. L-Amino acid standards (2.5 $\mu \mathrm{mol} / \mathrm{ml}$ in $0.1 \mathrm{~N} \mathrm{HCl}$ ) (Thermo Scientific, Illinois, USA) were used to identify the amino acids.

Table 5 The mineral and amino acid composition (as fed basis) of feeds containing five inclusion levels of sweet lupins fed to grower phase slaughter ostriches (Trial 1)

\begin{tabular}{|c|c|c|c|c|c|}
\hline & \multicolumn{5}{|c|}{ Diet number and percentage lupin inclusion level } \\
\hline & $1(0 \%)$ & $2(7.5 \%)$ & $3(15 \%)$ & $4(22.5 \%)$ & $5(30 \%)$ \\
\hline \multicolumn{6}{|l|}{ Minerals } \\
\hline Calcium (g/kg) & 12.2 & 15.2 & 14.9 & 12.2 & 14.4 \\
\hline Phosphorous (g/kg) & 6.00 & 7.60 & 7.40 & 6.40 & 7.25 \\
\hline Magnesium (g/kg) & 2.30 & 2.60 & 2.50 & 2.50 & 2.50 \\
\hline Sodium $(\mathrm{g} / \mathrm{kg})$ & 3.88 & 4.11 & 5.01 & 3.56 & 4.86 \\
\hline Manganese $(\mathrm{mg} / \mathrm{kg})$ & 210.9 & 279.8 & 257.8 & 345.6 & 273.6 \\
\hline Copper (mg/kg) & 14.3 & 16.8 & 16.8 & 20.3 & 19.3 \\
\hline Iron (mg/kg) & 333.5 & 332.4 & 393.4 & 357.8 & 268.6 \\
\hline Zinc (mg/kg) & 119.0 & 151.4 & 137.7 & 170.2 & 147.8 \\
\hline \multicolumn{6}{|l|}{ Amino acids (g/kg) } \\
\hline Lysine & 9.80 & 14.0 & 17.2 & 14.7 & 24.6 \\
\hline Methionine & 0.30 & 0.60 & 0.20 & 0.10 & 0.10 \\
\hline Arginine & 6.50 & 8.20 & 10.0 & 8.60 & 13.5 \\
\hline Threonine & 4.90 & 5.50 & 6.10 & 5.20 & 7.30 \\
\hline Tyrosine & 5.10 & 5.80 & 6.50 & 5.70 & 7.90 \\
\hline Aspartic acid & 13.0 & 14.9 & 16.1 & 13.6 & 19.2 \\
\hline Glutamic acid & 19.5 & 23.3 & 26.4 & 22.8 & 33.3 \\
\hline Serine & 6.10 & 7.00 & 7.90 & 6.70 & 9.70 \\
\hline Histidine & 2.30 & 2.60 & 2.70 & 2.20 & 3.10 \\
\hline Glycine & 5.30 & 6.10 & 6.80 & 5.80 & 8.30 \\
\hline Alanine & 6.10 & 6.80 & 7.40 & 6.50 & 8.70 \\
\hline Valine & 6.30 & 7.10 & 7.60 & 6.50 & 8.90 \\
\hline Phenylalanine & 6.60 & 7.40 & 7.90 & 6.80 & 9.20 \\
\hline Isoleucine & 5.20 & 6.00 & 6.50 & 5.50 & 7.80 \\
\hline Leucine & 11.2 & 12.6 & 13.7 & 12.1 & 16.2 \\
\hline
\end{tabular}


Table 6 The mineral and amino acid composition (as fed basis) of feeds containing five inclusion levels of bitter lupins fed to grower phase slaughter ostriches (Trial 2)

\begin{tabular}{|c|c|c|c|c|c|}
\hline & \multicolumn{5}{|c|}{ Diet number and percentage lupin inclusion level } \\
\hline & $1(0 \%)$ & $2(7.5 \%)$ & $3(15 \%)$ & $4(22.5 \%)$ & $5(30 \%)$ \\
\hline \multicolumn{6}{|l|}{ Minerals } \\
\hline Calcium (g/kg) & 12.2 & 15.2 & 14.9 & 12.2 & 14.4 \\
\hline Phosphorous (g/kg) & 6.00 & 7.60 & 7.40 & 6.40 & 7.25 \\
\hline Magnesium $(\mathrm{g} / \mathrm{kg})$ & 2.30 & 2.60 & 2.50 & 2.50 & 2.50 \\
\hline Sodium (g/kg) & 3.88 & 4.11 & 5.01 & 3.56 & 4.86 \\
\hline Manganese $(\mathrm{mg} / \mathrm{kg})$ & 210.9 & 262.8 & 262.9 & 241.2 & 321.2 \\
\hline Copper (mg/kg) & 14.3 & 15.8 & 18.1 & 15.8 & 17.2 \\
\hline Iron (mg/kg) & 333.5 & 322.2 & 385.2 & 371.8 & 304.3 \\
\hline Zinc (mg/kg) & 119.0 & 137.7 & 145.6 & 120.6 & 161.8 \\
\hline \multicolumn{6}{|l|}{ Amino acids $(\mathrm{g} / \mathrm{kg})$} \\
\hline Lysine & 9.80 & 13.1 & 16.4 & 13.5 & 23.0 \\
\hline Methionine & 0.30 & 0.24 & 0.18 & 0.20 & 0.06 \\
\hline Arginine & 6.50 & 8.10 & 9.70 & 8.78 & 12.9 \\
\hline Threonine & 4.90 & 5.26 & 5.63 & 4.72 & 6.35 \\
\hline Tyrosine & 5.10 & 5.61 & 6.13 & 5.20 & 7.15 \\
\hline Aspartic acid & 13.0 & 14.2 & 15.3 & 13.3 & 17.6 \\
\hline Glutamic acid & 19.5 & 22.7 & 25.8 & 21.9 & 32.1 \\
\hline Serine & 6.10 & 6.82 & 7.54 & 6.36 & 8.98 \\
\hline Histidine & 2.30 & 2.41 & 2.51 & 1.99 & 2.72 \\
\hline Glycine & 5.30 & 5.87 & 6.44 & 5.46 & 7.59 \\
\hline Alanine & 6.10 & 6.38 & 6.66 & 5.56 & 7.21 \\
\hline Valine & 6.30 & 6.65 & 7.01 & 6.08 & 7.72 \\
\hline Phenylalanine & 6.60 & 7.15 & 7.71 & 7.40 & 8.82 \\
\hline Isoleucine & 5.20 & 5.66 & 6.11 & 5.22 & 7.02 \\
\hline Leucine & 11.2 & 12.0 & 12.7 & 10.5 & 14.2 \\
\hline
\end{tabular}


Table 7 The mineral and amino acid composition (as fed basis) of feeds containing five inclusion levels of either sweet or bitter lupins fed to grower phase slaughter ostriches (Trial 3)

\begin{tabular}{|c|c|c|c|c|c|}
\hline & \multicolumn{5}{|c|}{ Diet number and percentage lupin inclusion level } \\
\hline & $\begin{array}{c}1 \\
(0 \%)\end{array}$ & $\begin{array}{c}2 \\
\text { (15\% Sweet) }\end{array}$ & $\begin{array}{c}3 \\
\text { (15\% Bitter) }\end{array}$ & $\begin{array}{c}4 \\
\text { (30\% Sweet) }\end{array}$ & $\begin{array}{c}5 \\
(30 \% \text { Bitter) }\end{array}$ \\
\hline \multicolumn{6}{|l|}{ Minerals } \\
\hline Calcium (g/kg) & 12.2 & 14.3 & 14.9 & 12.9 & 14.4 \\
\hline Phosphorous (g/kg) & 6.60 & 7.20 & 7.40 & 6.90 & 7.25 \\
\hline Magnesium (g/kg) & 2.30 & 2.50 & 2.50 & 2.40 & 2.50 \\
\hline Sodium (g/kg) & 3.88 & 4.89 & 5.01 & 5.31 & 4.86 \\
\hline Manganese $(\mathrm{mg} / \mathrm{kg})$ & 210.9 & 257.8 & 262.9 & 273.6 & 321.2 \\
\hline Copper (mg/kg) & 14.3 & 16.8 & 18.1 & 19.3 & 17.2 \\
\hline Iron (mg/kg) & 333.5 & 393.4 & 385.2 & 268.6 & 304.3 \\
\hline Zinc (mg/kg) & 119.0 & 137.7 & 145.6 & 147.8 & 161.8 \\
\hline \multicolumn{6}{|l|}{ Amino acids $(\mathrm{g} / \mathrm{kg})$} \\
\hline Lysine & 9.80 & 17.2 & 16.4 & 24.6 & 23.0 \\
\hline Methionine & 0.30 & 0.20 & 0.18 & 0.10 & 0.06 \\
\hline Arginine & 6.50 & 10.0 & 9.70 & 13.5 & 12.9 \\
\hline Threonine & 4.90 & 6.10 & 5.63 & 7.30 & 6.35 \\
\hline Tyrosine & 5.10 & 6.50 & 6.13 & 7.90 & 7.15 \\
\hline Aspartic acid & 13.0 & 16.1 & 15.3 & 19.2 & 17.6 \\
\hline Glutamic acid & 19.5 & 26.4 & 25.8 & 33.3 & 32.1 \\
\hline Serine & 6.10 & 7.90 & 7.54 & 9.70 & 8.98 \\
\hline Histidine & 2.30 & 2.70 & 2.51 & 3.10 & 2.72 \\
\hline Glycine & 5.30 & 6.80 & 6.44 & 8.30 & 7.59 \\
\hline Alanine & 6.10 & 7.40 & 6.66 & 8.70 & 7.21 \\
\hline Valine & 6.30 & 7.60 & 7.01 & 8.90 & 7.72 \\
\hline Phenylalanine & 6.60 & 7.90 & 7.71 & 9.20 & 8.82 \\
\hline Isoleucine & 5.20 & 6.50 & 6.11 & 7.80 & 7.02 \\
\hline Leucine & 11.2 & 13.7 & 12.7 & 16.2 & 14.2 \\
\hline
\end{tabular}

The CIE Lab-System describes colour according to three surface colour attributes namely $\mathrm{L}^{*}$ (lightness), $a^{*}$ (redness), and $b^{*}$ (yellowness). The $L^{*}$ coordinate represents the lightness (reflection) of the sample, where $0=$ black and $100=$ white. The $a^{*}$ coordinate signifies the red/green spectrum, where a positive value indicates the degree of redness and a negative value indicates that green pigments are being detected. The $b^{*}$ coordinate characterises the yellow/blue range, with a positive value indicating the degree of yellowness and a negative value indicating the degree of blueness (BYK-Gardner $\mathrm{GmbH}$ ). The surface colour of the finely ground feed samples was measured using a colour-guide $45 \% 0^{\circ}$ colorimeter with an aperture size of $20 \mathrm{~mm}$ and an illuminant/observer ratio of D65/10 (Catalogue number 6805, BYK-Gardner $\mathrm{GmbH}$, Geretsried, Germany). Calibration of the colorimeter was done using the standards provided (BYKGardner). The finely ground sample was spread evenly in a petri dish and five repeats were taken per measurement per sample.

Statistical analysis was performed using Statgraphics Centurion (Version 15; Statpoint, Inc., Virginia, USA), SAS Enterprise Guide (Version 9.2; SAS Institute Inc., Cary, USA) and Microsoft Office Excel 2010 (Version 14.0, Microsoft Corporation by Impressa Systems, Santa Rosa, California). Descriptive statistics were performed on the respective CIE Lab-System colour attributes $\left(L^{*}, a^{*}\right.$ and $\left.b^{*}\right)$ per diet for each trial to determine whether changes in colour could explain the differences observed in fed intake. A multifactor analysis of variance (ANOVA) was done for all three trials separately to determine which of the two main effects, day and diet, had a statistically significant effect on the mean dry matter intake (DMI) per bird per 
treatment diet. The multifactor ANOVA was also used to test whether there was a significant interaction between the two main effects. A one-way ANOVA was conducted to evaluate the mean DMI as well as the $\% \mathrm{DMI}$ per bird per day by diet. A regression analysis of the mean DMI per bird was done per treatment diet over the different lupin inclusion levels (\%) for Trial 1 (sweet lupins) and 2 (bitter lupins). Statistical differences were declared at $P<0.05$.

\section{Results}

Regarding the colour attributes in Trial 1 , the $L^{*}$ value of diet 2 differed $(P<0.05)$ from that of diets 3 and 4. The value of diet 1 did not differ from the rest of the diets $(P>0.05)$. No differences were observed for the $a^{*}$ attribute between the respective diets. The positive values are an indication that more red pigments than green pigments were detected in these feed samples. The $b^{*}$ attribute of diet 5 differed $(P<0.05)$ from diets 1, 2, 3 and 4, while diet 4 also differed $(P<0.05)$ from diets 2 and 3 (Table 8 ). Because all the values are positive, it is an indication that there are more yellow pigments than blue pigments present in the feed.

In Trial 2, the $L^{*}$ attribute of diet 5 differed $(P<0.05)$ from that of diets 2,3 and 4 . The $a^{*}$ attribute of diets 4 and 5 did not differ significantly from each other, but they differed $(P<0.05)$ from the $a^{*}$ value of diet 2. There was no difference between the $\mathrm{a}^{*}$ attributes of diet 1,4 and 5 , and the $\mathrm{a}^{*}$ values of diets 3,4 and 5 did not differ significantly. The $a^{*}$ values of diets 1 and 2 did not differ significantly. The $b^{*}$ attribute of diet 5 differed $(P<0.05)$ from the remaining four diets (Table 8$)$.

In Trial 3 , the $L^{*}$ attribute of diets 4 and 5 differed $(P<0.05)$ from diets 1,2 and 3 , while the $a^{*}$ attribute of diet 1 differed $(P<0.05)$ from diets 3,4 and 5 . The $b^{*}$ attribute of diet 1 and 3 did not differ $(P>0.05)$ from each other, but did differ $(P<0.05)$ from diets 2,4 and 5 The $b^{*}$ attributes of diets 2,4 and 5 , differed $(P$ $<0.05$ ) from each other and also from diets 1 and 2 (Table 8).

However, while statistically significant differences were observed between the diets for the colour attributes, these differences were small, making little visual difference in the appearance of the feeds.

Table 8 Descriptive statistics (mean \pm standard error) of the CIE Lab-System colour attributes $\left(L^{*}\right.$, $a^{*}$ and $\left.b^{*}\right)$ for diets with varying sweet and bitter lupin inclusion levels

\section{Lupin inclusion levels}

CIE Lab-System colour attributes per diet and percentage lupin inclusion level

$L^{*} \quad a^{*} \quad b^{*}$

Trial 1: Sweet lupins

$\begin{array}{cc}0 \% & 57.0^{\mathrm{ab}} \pm 0.90 \\ 7.5 \% & 60.0^{\mathrm{a}} \pm 1.51 \\ 15 \% & 56.4^{\mathrm{b}} \pm 0.50 \\ 22.5 \% & 55.0^{\mathrm{b}} \pm 1.72 \\ 30 \% & 60.4^{\mathrm{a}} \pm 1.14\end{array}$

$3.1^{\mathrm{a}} \pm 0.20$

$3.2^{\mathrm{a}} \pm 0.25$

$3.3^{\mathrm{a}} \pm 0.09$

$3.3^{\mathrm{a}} \pm 0.26$

$3.6^{\mathrm{a}} \pm 0.21$

$57.0^{\mathrm{ab}} \pm 0.90$
$56.3^{\mathrm{b}} \pm 1.32$
$55.5^{\mathrm{b}} \pm 0.54$
$55.1^{\mathrm{b}} \pm 1.29$
$59.4^{\mathrm{a}} \pm 0.26$

$3.1^{\mathrm{bc}} \pm 0.20$

$2.6^{\mathrm{c}} \pm 0.30$

$4.1^{\mathrm{a}} \pm 0.09$

$3.6^{\mathrm{ab}} \pm 0.29$

$3.7^{\mathrm{ab}} \pm 0.11$

$57.0^{\mathrm{b}} \pm 0.90$
$56.4^{\mathrm{b}} \pm 0.50$
$55.5^{\mathrm{b}} \pm 0.54$
$60.4^{\mathrm{a}} \pm 1.14$
$59.4^{\mathrm{a}} \pm 0.26$ $3.1^{\mathrm{c}} \pm 0.20$

$3.3^{\mathrm{bc}} \pm 0.09$

$4.1^{\mathrm{a}} \pm 0.09$

$3.6^{b} \pm 0.21$

$3.7^{\mathrm{ab}} \pm 0.11$

$$
\begin{gathered}
19.7^{\mathrm{cd}} \pm 0.14 \\
21.0^{\mathrm{b}} \pm 0.51 \\
20.7^{\mathrm{bc}} \pm 0.04 \\
19.3^{\mathrm{d}} \pm 0.43 \\
23.5^{\mathrm{a}} \pm 0.45
\end{gathered}
$$

$$
\begin{aligned}
& 19.7^{b} \pm 0.14 \\
& 20.3^{b} \pm 0.34 \\
& 19.9^{b} \pm 0.17 \\
& 19.7^{b} \pm 0.70 \\
& 22.8^{a} \pm 0.29
\end{aligned}
$$

$$
\begin{aligned}
& 19.7^{d} \pm 0.14 \\
& 20.7^{c} \pm 0.04 \\
& 19.9^{d} \pm 0.17 \\
& 23.5^{a} \pm 0.45 \\
& 22.8^{b} \pm 0.29
\end{aligned}
$$

\footnotetext{
${ }^{a-d}$ column means with different superscripts differ significantly $(P<0.05)$

Regarding feed intake, no interaction was found between the two main effects (day and diet) in any of the three trials ( $P=0.45,0.88$ and 0.99 for trials 1,2 , and 3 respectively) (Table 9 ).
} 
Table 9 Effect of day on feed intake for the three different feed preference trials containing either sweet or bitter lupins.

\begin{tabular}{cccc}
\hline Day & \multicolumn{3}{c}{ Feed intake $\mathbf{( k g )}$} \\
\cline { 2 - 4 } & $\begin{array}{c}\text { Trial 1 } \\
\text { Sweet }\end{array}$ & $\begin{array}{c}\text { Trial 2 } \\
\text { Bitter }\end{array}$ & $\begin{array}{c}\text { Trial 3 } \\
\text { Sweet \& Bitter }\end{array}$ \\
\cline { 2 - 4 } 1 & $635.57^{\mathrm{ab}} \pm 23.83$ & $865.17^{\mathrm{a}} \pm 41.44$ & $884.53^{\mathrm{a}} \pm 43.31$ \\
2 & $567.00^{\mathrm{bc}} \pm 23.83$ & $654.70^{\mathrm{b}} \pm 41.44$ & $739.33^{\mathrm{abc}} \pm 43.31$ \\
3 & $537.90^{\mathrm{c}} \pm 23.83$ & $643.37^{\mathrm{b}} \pm 41.44$ & $820.37^{\mathrm{ab}} \pm 43.31$ \\
4 & $582.10^{\mathrm{abc}} \pm 23.83$ & $735.07^{\mathrm{ab}} \pm 41.44$ & $661.73^{\mathrm{bc}} \pm 43.31$ \\
5 & $670.57^{\mathrm{a}} \pm 23.83$ & $727.87^{\mathrm{ab}} \pm 41.44$ & $633.13^{\mathrm{c}} \pm 43.31$
\end{tabular}

$\overline{{ }^{2,0} \text { Column means with different superscripts differ significantly }(P<0.05)}$

The main effects were therefore investigated individually and one-way ANOVA's were conducted to evaluate the effect of diet on the mean DMI and \%DMI per bird per day. The results for both mean DMI and $\% \mathrm{DMI}$ indicated that feed intake did not differ between the five diets for any of the three trials (Table 10).

Table 10 Least square means \pm standard error (LSM \pm SE) for the effect of sweet and bitter lupin inclusion levels on the mean DMI and \%DMI of grower phase slaughter ostriches

\begin{tabular}{ccccc}
\hline Lupin variety & $\begin{array}{c}\text { Treatment } \\
\text { diet }\end{array}$ & $\begin{array}{c}\text { Lupin inclusion level } \\
(\%)\end{array}$ & $\begin{array}{c}\text { Mean DMI/bird/day } \\
\mathbf{( g )}\end{array}$ & $\begin{array}{c}\text { Percentage of DMI/bird/day } \\
(\%)\end{array}$ \\
\hline & 1 & 0 & $541.13 \pm 35.43$ & $18.11 \pm 1.13$ \\
Sweet & 2 & 7.5 & $646.20 \pm 35.43$ & $21.52 \pm 1.13$ \\
Trial 1 & 3 & 15 & $628.07 \pm 35.43$ & $20.92 \pm 1.13$ \\
& 4 & 22.5 & $583.70 \pm 35.43$ & $19.62 \pm 1.13$ \\
& 5 & 30 & $594.03 \pm 35.43$ & $19.83 \pm 1.13$ \\
& & & & \\
Bitter & 1 & 0 & $776.10^{\mathrm{ab}} \pm 78.27$ & $21.30^{\mathrm{ab}} \pm 2.18$ \\
Trial 2 & 2 & 15 & $890.60^{\mathrm{a}} \pm 78.27$ & $24.46^{\mathrm{a}} \pm 2.18$ \\
& 3 & 22.5 & $606.57^{\mathrm{b}} \pm 78.27$ & $16.73^{\mathrm{b}} \pm 2.18$ \\
& 4 & 30 & $695.53^{\mathrm{ab}} \pm 78.27$ & $19.55^{\mathrm{ab}} \pm 2.18$ \\
& 5 & & $657.37^{\mathrm{b}} \pm 78.27$ & $17.97^{\mathrm{b}} \pm 2.18$ \\
& & & & \\
Sweet \& Bitter & 1 & 0 & $893.00 \pm 90.07$ & $23.60 \pm 2.34$ \\
Trial 3 & 2 & 15 (Sweet) & $628.23 \pm 90.07$ & $16.77 \pm 2.34$ \\
& 3 & 15 (Bitter) & $672.00 \pm 90.07$ & $17.84 \pm 2.34$ \\
& 4 & 30 (Sweet) & $736.97 \pm 90.07$ & $19.87 \pm 2.34$ \\
& 5 & 30 (Bitter) & $808.90 \pm 90.07$ & $21.92 \pm 2.34$ \\
\hline
\end{tabular}

${ }^{a, b}$ Column means with different superscripts differ significantly $(P<0.05)$

Regression analysis of DMI per bird per day on lupin inclusion level for trials 1 and 2 revealed no significant trend (Figure 1). A polynomial regression was fitted to both the trial 1 and $2 \mathrm{DMI}$ data, but the quadratic function was non-significant in both cases $(P=0.47$ and 0.62 , respectively). The regression equation for the first trial accounted for $52.56 \%$ of the variance while the regression equation for the second trial accounted for $38.45 \%$. These regression models therefore did not fit the data closely and do not describe the effect that lupin inclusion level has on DMI very accurately. 


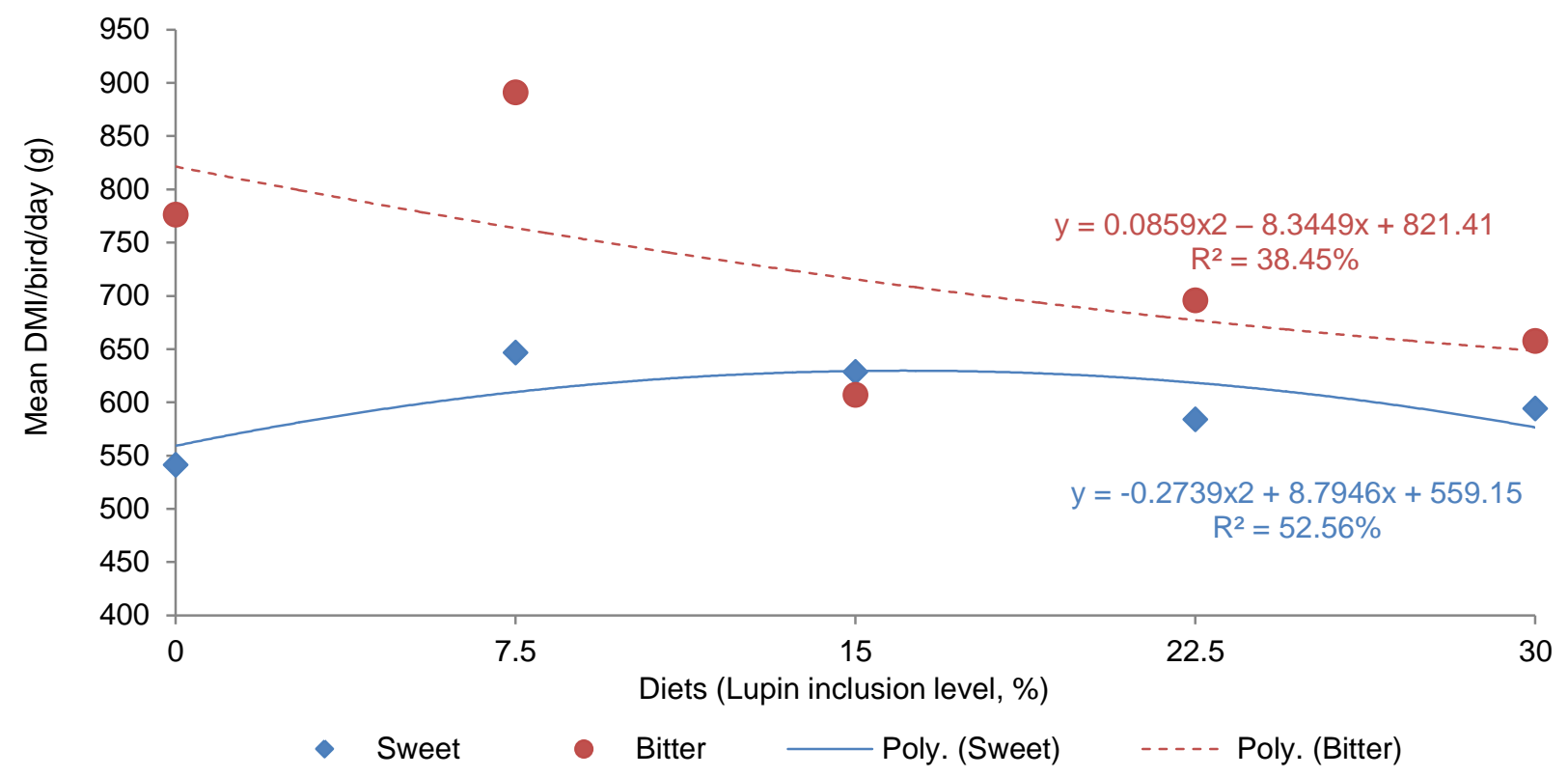

Figure 1 Quadratic functions fitted to the DMI of grower phase slaughter ostriches fed diets containing different inclusion levels of sweet and bitter lupins

\section{Discussion}

The results of this study indicated that the feed preference and intake of ostriches is not influenced by the inclusion of sweet lupins in the diet up to $30 \%$. This is unexpected as alkaloids are bitter-tasting compounds, reducing the palatability of the feed (Smith, 2005). Previous studies on poultry and pigs found that lupin inclusion tended to reduce palatability, which result in poor acceptance and growth rates (Petterson \& Fairbrother, 1996). The results found in Trial 1 of this study may be due to the low alkaloid content of the sweet lupin diets used. The prolonged consumption of the sweet lupin diets should therefore be acceptable for ostriches of the age groups tested.

Kruger et al. (2008) fed a conventional pre-starter mash diet (as formulated by Brand, 2005) artificially flavoured with four different commercially-produced non-toxic food flavourants (sweet, bitter, salty and sour) to ostrich chicks in a free-choice setup with no previous exposure to any of the feeds. It was concluded that the chicks preferred salty feed $(34.0 \%)$, then sweet $(17.9 \%)$, control $(17.1 \%)$, bitter $(15.7 \%)$, and sour $(15.4 \%)$. This result could be attributed to the evolution of ostriches in deserts where the availability of good quality water is limited, for ostriches are able to utilise water with high salt levels due to their salt-excretory nasal glands (Kruger, 2007). It was not considered likely that the choice of salty food was directly related to flavour as Brand et al. (2008b) found that there were no conventional taste buds present in either two-monthold chicks or adult ostriches. If it is likely that ostriches cannot taste, and that the tendency for the ostriches to prefer the $7.5 \%$ bitter lupin inclusion level while discriminating to some extend against the $15 \%$ and $30 \%$ inclusion levels (Trial 2; Table 10) could therefore be attributed to the small sample size used rather than any particular pattern of feed-choice. It is thus possible that some other factor of the feed apart from its visual appearance, palatability thereof or the birds' previous experience may have played a role in producing this trend, for the bitter lupin diets had a much higher alkaloid content compared to the sweet lupin diets. Discrimination against the bitter lupin diets would thus almost be expected, but during Trial 3 both the mean $\mathrm{DMI}$ and \%DMI indicated that feed intake did not differ between the five diets.

The oropharyngeal cavity of the ostrich as well as its components (beak, hard palate, pharynx, tongue and the larynx) was studied by Tadjalli et al. (2008). It was found that the caudal third portion of the hard palate contains a semi-circular darker area that is covered by many small delicate papillae. The other two thirds of the rostral part of the hard palate, that divides it into two regions, lack papillae. The ostrich also lacks a transverse row of papillae caudal to the infundibular opening at the junction with the oesophagus. While Gentle (1971) stated that chickens have a good sense of taste, Kare and Pick (1960) noted that despite the selection against bitter components when under free-choice conditions, a very high concentration bitter-tasting substances in feed is required over long periods before any reduction in feed intake is 
observed. The tendency observed during Trial 2 may therefore warrant further research, since the question of how important taste is in determining palatability in this species might rise.

Ferguson et al. (2002) noted that when young pigs were given a choice of diets, they instinctively avoided potentially harmful substances (toxins), anti-nutritional factors or unpalatable components in the feeds. Thereafter, they selected more nutritionally balanced feeds or feeds with more favourable amino acid profiles that would satisfy their requirements for growth and production. The iso-nitrogenous nature of the diets used in this study, together with the low alkaloid contents found in the sweet lupin diets, as well as the seemingly absence of taste in ostriches could explain for the lack of variation in DMI between the five diets during Trial 3.

During the evaluation of lupins in the diets of pigs and poultry, it was found that the maximum lupin inclusion levels for pigs are as follows: $10-15 \%$ in starter diets, $20-25 \%$ in grower diets, $30-35 \%$ in finisher diets and $20 \%$ in dry and lactating sow diets (Petterson \& Fairbrother, 1996). Inclusion levels of up to $25 \%$ of low-alkaloid lupin-seed meal can be tolerated by broiler chickens without affecting growth unfavourably (Brenes et al., 1993). Research has also shown that a maximum inclusion level of $25-35 \%$ of either $L$. angustifolius or $L$. albus will not affect the laying performance of hens (Edwards and van Barneveld, 1998), while in broiler chicken diets it should not exceed $10 \%$.

Forbes and Shariatmadari (1994) stated that when a single feed is provided, the intake is determined primarily by the energy content thereof. This is supported by Rose and Kyriazakis (1991), who reported that one of the major factors determining the diet selection of poultry and pigs are their nutrient requirements. Brand et al. (2012) consequently assumed that male and female South African Black ostriches would select feeds under free-choice feeding conditions according to their protein and energy requirements. In this study, the treatment diets were formulated to be iso-caloric (equal ME levels), while also meeting the requirements of the birds and although the diets did differ slightly in terms of their CP, fat, and CF contents, these differences were unlikely to have been great enough to have had a significant effect on diet selection and DMI (Table 2 - 4). The results from this study, indicate that DMI and \%DMI did not differ between the five treatments in any of the three trials, it also suggests that the diets provided satisfied the nutrient requirements of the birds.

Although significant differences were observed in the CIE Lab-System values between the feeds, colour of the feed not differ to any great extent under visual inspection (light yellowish-brown) (Table 8). The differences in colour therefore may have not been great enough to cause any difference in feed preference and intake. It must also be noted that the pattern of feed preference and intake observed during Trial 2 for the DMI and \%DMI did not correspond with the differences observed in the colour attributes. It is therefore not clear whether the colour of the feed influenced the feed preference and intake of the birds, but it appears that some other factors apart from colour may have had a more important influence for determining feed preference. This is in contrast to the findings of Bubier et al. (1996), who provided strips of insulation tape of different colours (green, white, red, blue, yellow, and black) to chicks and found that the green tape produced the greatest pecking response. This can be related to the herbivorous nature of the ostrich in the wild. The second colour of preference was white, which can be related to the coprophagy of adult dung, which is usually accompanied by white urate deposits. However, the results obtained in this study correspond with the results of Brand et al. (2008a), who found that while chicks showed a preference for green plastic strips they did not distinguish between feeds of different colours. In addition, Kruger (2007) found that chicks preferred an untreated pre-starter diet (mash and light brown in colour) to artificially coloured feeds. The question now arises whether ostriches base their choice of feed selection on the colour of the feed and may therefore warrant further research.

According to Forbes and Covasa (1995), feed intake in a free-choice feeding system does not only depend on the metabolic requirements or physiological state of the chicken, but also on factors such as previous experience and social interactions. They advise exposing pullets to all the grains that they may be offered later in life during the rearing period in order to allow them to learn their nutritional characteristics. Rose et al. (1986), as well as Forbes and Covasa (1995) also suggested that the type, form and nutrient content of the feed has a profound effect on diet selection. Factors such as trough design, position of the trough, breed, sex, management, and genetics may also contribute to determining which diet is selected by the birds. In this study, lupins were the only component of the diet to which the birds had not been exposed to previously. In addition, all other possibly influential factors were kept constant and were the same for all the paddocks in order to reduce the risk of any outside influences on diet selection. 


\section{Conclusion}

The results of this study indicate that soybean oilcake meal can be replaced in the diets of grower phase ostriches by sweet lupin inclusion levels of up to $30 \%$ without any significant effect on feed selection. The tendency of the birds to discriminate to some extend against higher percentages of bitter lupin diets may warrant further research. In this study the inclusion levels of sweet and bitter lupins, replacing soybean oilcake meal, were only up to $30 \%$. Further studies will be required to evaluate the effect of higher levels of lupins on feed intake. Lupins are widely used as raw material in livestock feeds as it is cost-competitive with multiple other protein sources. Results from this study may assist in establishing a potential market for lupins as well as improving the profit margins of ostrich farmers and the local grain legume industry.

\section{Acknowledgements}

Acknowledgements are hereby made to the Western Cape Department of Agriculture for joint funding of the study, as well as the personnel in their employment for their aid. In addition, the Western Cape Agricultural Research Trust for the joint funding of the study.

\section{Authors' Contributions}

Concept and design: TSB; data collection and analysis: JAE; drafting of paper: JvdM; critical revision and final approval of version to be published: LCH.This statement is to certify that all the authors of this paper made substantial contributions to conception and design, and/or acquisition of data, and/or analysis and interpretation of data. All the authors have seen and approved the manuscript being submitted.

\section{Conflict of Interest Declaration}

The authors certify that they have no affiliations with or involvement in any organization or entity with financial or non-financial interest in the subject matter and materials discussed in this manuscript.

\section{References}

ALASA, 1998. Method 6.1.1 - Dry ashing. In: Handbook of feeds and plant analysis. Ed: Palic, D., Hatfield, Pretoria, South Africa.

AOAC, 2002. Official Methods of analysis. In: Association of Official Analytical Chemists (17th ed.). Inc., Virginia, U.S.A., Arlington. pp. 152-169.

Boschin, G., Annicchiarico, P., Resta, D., D’Agostina, A. \& Arnoldi, A., 2008. Quinolizidine Alkaloids in Seeds of Lupin Genotypes of Different Origins. J. Agric. Food Chem. 56, 3657-3663.

Brand, T.S., 2005. Ostrich Feeding. In: Technical Brochure 1. Elsenburg Research Centre, Private Bag x1, Elsenburg, 7607.

Brand, T.S., 2008. Selection of food. In: Ostrich Nutrition: A Scientific Approach. Stellenbosch, South Africa, Sun Print. pp. 18-20.

Brand, T.S. \& Brandt, D.A., 2000. Alkaloid content of South African lupins ( $L$ luteus, $L$ albus and $L$ angustifolius species) and determination thereof by Near Infra-red Reflectance Spectroscopy. S. Afr. J. Anim. Sci. 30, 11-12 (Supplement 1).

Brand, T.S., Brandt, D.A. \& Cruywagen, C.W., 2004a. Chemical composition, true metabolisable energy content and amino acid availability of grain legumes for poultry. S. Afr. J. Anim. Sci. 34(2), 116-122.

Brand, T.S., Franck, F., Brand, A.A., Durand, A. \& Coetzee, J., 1992. An evaluation of fababean (Vicia faba) and lupin (Lupinus albus) stubble and seed for sheep. S. Afr. J. Anim. Sci. 22(5), 170-174.

Brand, T.S., Franck, F., Durand, A. \& Coetzee, J., 1997. Intake and production of ewes grazing oat stubble supplemented with sweet lupin (Lupinus albus) seed. Small Rumin. Res. 26, 93-103.

Brand, T.S. \& Gous, R.M., 2006. Feeding Ostriches. In: Feeding in domestic vertebrates: From a structure behaviour. Ed: Bels, V., Wallingford, England, CAB International. pp. 136-155.

Brand, T.S., Gous, R.M., Kruger, A.C.M., Brand, Z., Nel, J., Aucamp, B.B. \& Engelbrecht, S., 2004b. Mathematical feeding optimization model for ostriches: Recent progress in the prediction of nutrient requirements for slaughter and breeder birds. Invited review at the Ostrich Information Day of the South African Ostrich Producers Organisation, June 2004. pp. 1-13 (in Afrikaans).

Brand, T.S., Janse van Vuuren, M. \& Aucamp, B.B., 2008a. Studies on the feeding behaviour behaviour of ostrich chickens. Proceedings of the Ostrich Information day, Oudtshoorn, South Africa, June 2008.

Brand, T.S., Kritzinger, W.J., Hoffman, L.C. \& Gous, R.M., 2012. A description of body growth and composition of South African Black ostriches (Struthio camelus var. domesticus) under free-choice feeding conditions. S. Afr. J. Anim. Sci. 42(5), 555-558 (Supplement 1).

Brand, T.S., Kruger, A.C.M. \& Aucamp, B.B., 2008b. The effect of feeding management practises on the feed intake and production performance of newly hatched ostrich chickens. Proceedings of the Ostrich Information day, Oudtshoorn, South Africa, June 2008.

Brand, T.S., Nell, C.J. \& van Schalkwyk, S.J., 2000. Preliminary results on the effect of dietary energy and protein levels on the production of male breeding ostriches. S. Afr. J. Anim. Sci. 30, 15-16 (Supplement 1).

Brand, T.S., Olckers, R.C. \& van der Mewe, J.P., 1995. Evaluation of faba beans (Vicia faba cv. Fiord) and sweet lupins (Zupizus albus cv. Kiev) as protein sources for growing pigs. S. Afr. J. Anim. Sci. 25(2), 31-35.

Brenes, A., Marquardt, R.R., Guenter, W. \& Rotter, B.A., 1993. Effect of enzyme supplementation on the nutritional value of raw, autoclaved, and dehulled lupins (Lupinus albus) in chicken diets. Poult. Sci. 72, 2281-2293. 
Bubier, N.E., Lambert, M.S., Deeming, D.C., Ayres, L.L. \& Sibly, R.M., 1996. Time budget and colour peferences (with specific reference to feeding) of ostrich (Struthio camelus) chicks in captivity. Br. Poult. Sci. 37, 547-551.

Carstens, P.D., 2013. Studies to develop a mathematical optimisation model to describe the effect of nutrition on the growth of ostriches (Struthio camelus var. domesticus). MS.c. (Agric) thesis, University of Stellenbosch, South Africa.

Edwards, R A. \& van Barneveld, R.J., 1998. Lupins for livestock and fish. In: Lupins as crop plants: biology, production and utilization. Eds: Gladstones, J.S., Atkins, C. \& Hamblin, J., Cambridge, CAB International, University Press. pp. 385-409.

Ferguson, N.S., Bradford, M.M.V. \& Gous, R.M., 2002. Diet selection priorities in growing pigs offered a choice of feeds. S. Afr. J. Anim. Sci. 32(2), 136-143.

Forbes, J.M. \& Covasa, M., 1995. Application of diet selection by poultry with particular reference to whole cereals. World's Poult. Sci. J., 51(2), 149-165.

Forbes, J.M. \& Shariatmadari, F., 1994. Diet selection for protein by poultry. World's Poult. Sci. J. 50(1), 7-24.

Gentle, M.J., 1971. Taste and its importance to the domestic chicken. Br. Poult. Sci. 12, 77-86.

Goering, H.K. \& van Soest, P.J., 1970. Forage Fibre Analyses (Apparatus, reagents, procedures and some applications). In: Agricultural Handbook No. 379, USDA-ARS, U.S. Department of Agriculture Washington.

Grace Davison, 2008. Sensitive analysis of Amino Acids with OPA-3 Column by precolumn derivatisation with orthoPhthaldialdehyde. pp. 1-7.

Jordaan, J.W., Brand, T.S., Bhiya, C. \& Aucamp, B.B., 2008. An evaluation of slaughter age on the profitability of intensive slaughter ostrich production. Aust. J. Exp. Agr. 48(7), 916-920.

Kare, M.R. \& Pick, H.L., 1960. The influence of the sense of taste on feed and fluid consumption. Poult. Sci., 39, 697706.

Kruger, A.C.M., 2007. The effect of different management practises on the feed intake and growth rate of ostrich chicks. M.Tech. (Agric) Thesis, Nelson Mandela Metropolitan University, South Africa.

Kruger, A.C.M., Brand, T.S. \& Aucamp, B.B., 2008. The effect of artificially flavoured mash on the feed intake of ostrich chicks. Proceedings of the 26th Annual Congress of the South African society for Agricultural Technology, West Coast, South Africa, 16-19 September 2008.

Laudadio, V. \& Tufarelli, V., 2011. Dehulled-micronised lupin(Lupinus albus L. cv. Multitalia) as the main protein source for broilers: influence on growth performance, carcass traits and meat fatty acid composition. J. Sci. Food Agric., 91, 2081-2087.

McDonald, P., Edwards, R.A., Greenhalgh, J.F.D., Morgan, C.A., Sinclair, L.A. \& Wilkinson, R.A., 2011. Animal Nutrition (7th ed.). UK, Europe, Pearson. pp. 6.

Milton, S.J., Dean, W.R.J. \& Siegfried, W.R., 1994. Food selection by ostrich in Southern Africa. J. Wildlife Manage. 58(2), 234-248.

Petterson, D.S. \& Fairbrother, A.H., 1996. Lupins as a Raw Material for Human Foods and Animal Feeds. Indonesian Food Nutr. Prog. 3(2), 35-41.

Robertson, J.B. \& van Soest, P.J., 1981. The detergent system of analysis and its application to human foods. In: Basic and clinical nutrition, Vol 3. Eds: James, W.P.T. \& Theander, O., New York, USA, Marcel Dekker Inc. pp. 158276.

Rose, S.P., Burnett, A. \& Elmajeed, R.A., 1986. Factors affecting the diet selection of choice-fed broilers. Br. Poult. Sci. 27(2), 215-224.

Rose, S.P. \& Kyriazakis, I., 1991. Diet selection of pigs and poultry. Proc. Nutr. Soc. 50, 87-98.

Smith, N., 2005. The effect of the dietary inclusion of canola oilcake, full-fat canola and sweet lupins on the production performance and fat composition of broilers and pigs. MSc. (Agric) Thesis, University of Stellenbosch, South Africa.

Tadjalli, M., Mansouri, S.H. \& Poostpasand, A., 2008. Gross anatomy of the oropharyngeal cavity in the ostrich (Struthio camelus). Iran. J. Vet. Res., Shiraz University, Vol. 9. 4(25), 316-323.

Tilley, J.M.A. \& Terry, R.A., 1963. A two-stage technique for the in vitro digestion of forage crops. J. Br. Grassl. 18(2), 104-111.

Tufarelli, V, Demauro, V. \& Laudadio, V. 2015. Dietary micronized-dehulled white lupin (Lupinus albus L.) in meat-type guinea fowls and its influence on growth performance, carcass traits and meat lipid profile. Poult. Sci. 94(10), 2388-2394.

Van der Honing, Y. \& Alderman, G., 1988. Ruminants. In: Feeds \& Feedstuffs in Europe: Livestock Production Science, Vol. 19. Eds: Bickel, H. \& De Boer, F., The Netherlands, Elsevier Science Publishers B.V., Amsterdam. pp. 227.

Von Baer, D., Reimerder, E.H. \& Felcheim, W., 1978. Methoden zur Bestimmung der Chinolizidin alkaloide in Lupinus mutabilis. Zeitschrift für Lebensmittel Untersuchung und Forschung. 16q, $27-31$. 


\section{APPENDIX 1}

The composition of the vitamin and mineral premix used in the four ostrich feeding phases (pre-starter, starter, grower and finisher) formulated per ton of feed.

\begin{tabular}{lccc}
\hline \multirow{2}{*}{$\begin{array}{l}\text { Ingredients } \\
\text { (Composition per unit of premix) }\end{array}$} & \multicolumn{3}{c}{ Stage of growth } \\
\cline { 2 - 4 } Vitamin A & Units & Pre-Starter \& Starter & Grower \& Finisher \\
Vitamin D3 & $\mathrm{IU}$ & 15000000 & 12000000 \\
Vitamin E & $\mathrm{IU}$ & 4000000 & 3000000 \\
Vitamin K3 stab & $\mathrm{mg}$ & 60000 & 40000 \\
Vitamin B1 & $\mathrm{mg}$ & 3000 & 3000 \\
Vitamin B2 & $\mathrm{mg}$ & 5000 & 3000 \\
Vitamin B6 & $\mathrm{mg}$ & 10000 & 8000 \\
Vitamin B12 & $\mathrm{mg}$ & 8000 & 6000 \\
Niacin & $\mathrm{mg}$ & 100 & 100 \\
Pantothenic Acid & $\mathrm{mg}$ & 100000 & 80000 \\
Folic Acid & $\mathrm{mg}$ & 15000 & 12000 \\
Biotin & $\mathrm{mg}$ & 3000 & 2000 \\
Choline & $\mathrm{mg}$ & 300 & 200 \\
Magnesium & $\mathrm{mg}$ & 800000 & 600000 \\
Manganese & $\mathrm{mg}$ & 50000 & 50000 \\
Iron & $\mathrm{mg}$ & 120000 & 120000 \\
Zinc & $\mathrm{mg}$ & 30000 & 25000 \\
Copper & $\mathrm{mg}$ & 120000 & 80000 \\
Cobalt & $\mathrm{mg}$ & 8000 & 8000 \\
lodine & $\mathrm{mg}$ & 300 & 100 \\
Selenium & $\mathrm{mg}$ & 2000 & 1000 \\
& $\mathrm{mg}$ & 300 & 300 \\
\hline * & & & \\
\hline
\end{tabular}

${ }^{*} R E C O M M E N D A T I O N$ : To make half ton of feed divide premix pack into two parts. 